\title{
ע Turvallisuuden edistäminen iäkkäiden tehostetussa palveluasumisessa
}

\author{
Outi Kiljunen ${ }^{1}$,Tarja Välimäki ${ }^{1}$, Pirjo Partanen ${ }^{1}$, Päivi Kankkunen ${ }^{1}$ \\ ${ }^{1}$ Hoitotieteen laitos, Terveystieteiden tiedekunta, Itä-Suomen yliopisto
}

\begin{abstract}
Turvallisuus on olennainen osa sosiaali- ja terveydenhuollon palvelujen laatua. Asumispalveluyksiköissä asuvien iäkkäiden turvallisuuden edistäminen edellyttää monenlaisia toimia, sillä huomioon tulee ottaa asumisen, hoidon, hoivan ja tukipalvelujen turvallisuus. Kattava kuvaus asukasturvallisuuden edistämisen toimista asumispalveluyksiköissä puuttuu. Tässä artikkelissa kuvataan asukasturvallisuuden edistämistä iäkkäiden tehostetussa palveluasumisessa dokumenttianalyysin pohjalta. Tutkimusaineisto koostui iäkkäiden palveluja ja asumispalveluyksiköitä Suomessa koskevista laeista, suosituksista, määräyksistä ja ohjeista $(n=26)$. Aineisto analysoitiin temaattisella analyysillä. Tulosten mukaan asukasturvallisuutta edistetään iäkkäiden tehostetun palveluasumisen yksiköissä suunnitelmallisella omavalvonnalla ja omatoimisella varautumisella, moniammatillisella yhteistyöllä sekä lupa- ja valvontaviranomaisten toimilla ongelmatilanteissa. Asukasturvallisuuden edistämisessä korostuu johdon vastuu, mutta omavalvonta kuuluu jokaiselle yksikön työntekijälle. Lisäksi tulisi hyödyntää omaisten ja asukkaiden palaute, näkemykset ja huomiot asukasturvallisuudesta. Moniammatillista yhteistyötä tarvitaan asumisen ja palvelujen turvallisuuden takaamiseksi. Esimerkiksi terveydenhuollon asiantuntemusta tulee olla käytettävissä riittävästi. Pyrittäessä edistämään iäkkäiden asumispalveluyksiköissä asuvien turvallisuutta on tärkeää tiedostaa eri tahojen roolit sekä varmistua riittävästä osaamisesta ja resurssista asukasturvallisuustyössä.
\end{abstract}

\section{Johdanto}

Iäkkäiden palveluihin liittyvien kantelujen ja epäkohtailmoitusten määrä kasvoi Suomessa vuonna 2019 (Valvira 2020a). Ne kohdistuivat muun muassa asukasturvallisuuteen (EteläSuomen aluehallintovirasto/Aluehallintovirastojen hallinto- ja kehittämispalvelut 2020), joka sisältää asumiseen, hoitoon, hoivaan ja muihin palveluihin liittyvän turvallisuuden (Saarsalmi
\& Koivula 2017). Asukasturvallisuutta koskevien vastuiden ja velvollisuuksien tunnistaminen on edellytys hoidon ja palveluiden laadun kehittämiselle.

Tehostettu palveluasuminen on asumispalveluihin luettava sosiaalihuollon palvelumuoto, jota järjestetään ympärivuorokautista hoitoa ja huolenpitoa tarvitseville henkilöille (Sosiaalihuoltolaki 1301/2014 § 21). Se ei kuulu laitospalveluihin (kuten vanhainkodit ja terveyskes- 
kusten vuodeosastot), vaan asiakas maksaa erikseen asumisesta, lääkkeistä ja palveluista (Noro \& Alastalo 2014). Palveluihin sisältyvät hoito ja huolenpito, toimintakykyä ylläpitävä ja edistävä toiminta, ateria-, vaatehuolto-, peseytymis- ja siivouspalvelut sekä osallisuutta ja sosiaalista kanssakäymistä edistävät palvelut (Sosiaalihuoltolaki 1301/2014 §21). Palvelut on toteutettava siten, että iäkäs henkilö voi kokea elämänsä turvalliseksi, merkitykselliseksi ja arvokkaaksi (Vanhuspalvelulaki 980/2012 $\S 14)$. Suomessa tehostettua palveluasumista tuottavat kunnat ja kuntayhtymät sekä yksityiset palveluntuottajat, joita koskevat pääosin samat lait. Julkisen sektorin toimijat eivät kuitenkaan tarvitse lupaa sosiaalipalvelujen tuottamiseen toiminnan aloitusvaiheessa kuten yksityiset palveluntuottajat (Laki yksityisistä sosiaalipalveluista 922/2011 §7).

Tehostetun palveluasumisen asiakasmäärä on 2000-luvulla kasvanut jatkuvasti laitoshoidon vähentyessä (Anttonen \& Karsio 2016). Tehostetussa palveluasumisessa oli Suomessa vuoden 2018 lopussa asiakkaita 44959 eli 7,6 prosenttia 75 vuotta täyttäneistä (THL 2019). Valtaosalla iäkkäiden tehostetun palveluasumisen asiakkaista on muistisairaus, ja muun muassa tämän vuoksi he tarvitsevat erityistä suojelua (Alzheimer Europe 2018). Asiakasturvallisuus on sitä, että palvelut, huolenpito ja hoito edistävät asiakkaan fyysistä, psyykkistä ja sosiaalista hyvinvointia ja niistä aiheutuu mahdollisimman vähän haittaa (STM 2017). Palvelujen laadun ja turvallisuuden perustan muodostaa omavalvonta (STM 2020a), jota valvovat viranomaiset tukevat ensisijaisesti ohjauksella ja neuvonnalla (Valvira 2020b). Asukasturvallisuustyö tehostetussa palveluasumisessa vaatii eettistä herkkyyttä ja pohdintaa, sillä turvallisuutta edistävät toimenpiteet ovat herkästi ristiriidassa asukkaiden itsemääräämisoikeuden kanssa (Evans ym. 2018).

Viime vuosina on enenevissä määrin tutkittu esimerkiksi turvallisuuskulttuurin vaikutusta haittatapahtumien (kuten lääkehoitovirheiden, putoamisten ja kaatumisten) esiintymiseen.
Tutkimus on kuitenkin ensisijaisesti keskittynyt laitoshoitoon, ja asukasturvallisuuden edistämisestä asumispalveluissa tarvitaan lisää tietoa (Gartshore ym. 2017). Tässä artikkelissa kuvataan asukasturvallisuuden edistämistä tehostettua palveluasumista tarjoavissa asumispalveluyksiköissä dokumenttianalyysin pohjalta. Tavoitteena oli ymmärtää ja tehdä näkyväksi asukasturvallisuuden edistämisen kokonaisuutta, vastuita ja velvollisuuksia iäkkäiden tehostetussa palveluasumisessa. Dokumenttianalyysillä vastattiin kysymykseen: Miten iäkkäille tehostettua palveluasumista tarjoavissa yksiköissä asuvien turvallisuutta pyritään edistämään ja mitkä tahot ovat vastuussa näistä toimista? Sosiaalihuoltoa koskevissa lakiteksteissä sekä suosituksissa ja ohjeissa käytetään termiä asiakasturvallisuus. Tässä artikkelissa on käytetty termiä asukasturvallisuus (resident safety), koska tarkastelun kohteena on turvallisuus asumispalvelukontekstissa.

\section{Aineisto ja menetelmät}

\section{Dokumenttianalyysin aineisto}

Tutkimuskysymykseen vastattiin dokumenttianalyysin pohjalta. Dokumenttianalyysiin päädyttiin, koska se paitsi toimii itsenäisenä tutkimusmenetelmänä, tarjoaa myös lähtökohdan yksityiskohtaisemmalle asukasturvallisuuden edistämisen tutkimukselle (Bowen 2009). Dokumenttianalyysin aineisto koostui Suomessa iäkkäiden palveluja ja tehostettua palveluasumista tarjoavia asumispalveluyksiköitä koskevista asukasturvallisuuteen liittyvistä lakiteksteistä, suosituksista, määräyksistä ja ohjeista $(n=26)$, jotka olivat voimassa 24.6.2020 (taulukko 1).

Dokumenttien etsimisessä hyödynnettiin Sosiaali- ja terveysalan lupa- ja valvontaviraston (Valvira) internetsivuilta löytyvää sosiaalipalvelujen omavalvontasuunnitelman ohjetta. Se sisältää viittauksia sosiaalihuollon palveluja koskeviin lakeihin, määräyksiin ja ohjeisiin 
sekä asukasturvallisuusasioihin. Lisäksi hyödynnettiin muun muassa aluehallintovirastojen käytössä olevaa valvontakäyntien tarkastuskertomuspohjaa, joka sisältää iäkkäille tehostettua palveluasumista tuottavia yksiköitä koskevia lakeja, suosituksia ja ohjeita. Valviran internetsivuilta etsittiin myös tutkimuskontekstiin liittyvät ohjeet. Tämän lisäksi käytiin läpi voimas- sa olleet sosiaalihuollon asumispalveluyksiköitä koskevat koronaviruspandemiaan liittyvät suositukset ja ohjeet sosiaali- ja terveysministeriön internetsivuilta. Mukaan dokumenttianalyysiin otettiin lait, määräykset, suositukset ja ohjeet, joita iäkkäiden tehostetun palveluasumisen yksiköissä tulee tai on suositeltavaa noudattaa.

Taulukko 1. Analysoidut dokumentit.

\begin{tabular}{|c|c|}
\hline \multirow[t]{17}{*}{ Lait } & Elintarvikelaki 23/2006. \\
\hline & Holhoustoimilaki 1999/442. Laki holhoustoimesta. \\
\hline & Laki sosiaalihuollon ammattihenkilöistä 817/2015. \\
\hline & Laki sosiaalihuollon asiakasasiakirjoista 254/2015. \\
\hline & Laki sosiaali- ja terveydenhuollon palvelusetelistä 569/2009. \\
\hline & Laki terveydenhuollon ammattihenkilöistä 559/1994. \\
\hline & Laki terveydenhuollon laitteista ja tarvikkeista 629/2010. \\
\hline & Laki yksityisistä sosiaalipalveluista 922/2011. \\
\hline & Pelastuslaki 379/2011. \\
\hline & Potilaslaki 1992/785. Laki potilaan asemasta ja oikeuksista. \\
\hline & Suomen perustuslaki 731/1999. \\
\hline & $\begin{array}{l}\text { Sosiaalihuollon asiakaslaki 812/2000. Laki sosiaalihuollon asiakkaan asemasta } \\
\text { ja oikeuksista. }\end{array}$ \\
\hline & Sosiaalihuoltolaki 1301/2014. \\
\hline & Tartuntatautilaki 1227/2016. \\
\hline & Terveydenhuoltolaki 1326/2010. \\
\hline & Terveydensuojelulaki 763/1994. \\
\hline & $\begin{array}{l}\text { Vanhuspalvelulaki 980/2012. Laki ikääntyneen väestön toimintakyvyn tukemisesta } \\
\text { sekä iäkkäiden sosiaali- ja terveyspalveluista. }\end{array}$ \\
\hline Määräykset & $\begin{array}{l}\text { Valviran määräys 1/2014. Yksityisten sosiaalipalvelujen ja julkisten } \\
\text { vanhuspalvelujen omavalvontasuunnitelman sisältöä, laatimista ja seurantaa } \\
\text { koskeva määräys. }\end{array}$ \\
\hline \multirow[t]{8}{*}{$\begin{array}{l}\text { Suositukset, } \\
\text { ohjeet }\end{array}$} & $\begin{array}{l}\text { STM. Laatusuositus hyvän ikääntymisen turvaamiseksi ja palvelujen } \\
\text { parantamiseksi 2017-2019. STM julkaisuja 2017:6. }\end{array}$ \\
\hline & $\begin{array}{l}\text { VRN \& THL. Vireyttä seniorivuosiin - ikääntyneiden ruokasuositus. Valtion } \\
\text { ravitsemusneuvottelukunta ja THL Ohjaus 4/2020. }\end{array}$ \\
\hline & $\begin{array}{l}\text { STM ohje VN/8243/2020. Covid-19 aiheuttaman poikkeustilan huomioiminen } \\
\text { sosiaalihuollon asumispalveluyksiköiden lääkehuollossa. }\end{array}$ \\
\hline & $\begin{array}{l}\text { STM ohje VN/7643/2020. Tartuntatautilain ja valmiuslain vaikutus } \\
\text { liikkumisvapauteen sosiaalihuollon yksiköissä. (Siltä osin kuin ohjeessa viitataan } \\
\text { valmiuslain valtuuksiin, ohjeet eivät voimassa.) }\end{array}$ \\
\hline & $\begin{array}{l}\text { STM ohje } 15 \cdot 5 \cdot 2020 \text {. Koronavirustartuntojen ehkäisy ympärivuorokautisen hoidon } \\
\text { ja huolenpidon toimintayksiköissä. }\end{array}$ \\
\hline & $\begin{array}{l}\text { Inkinen, R., Volmanen, P. \& Hakoinen, S. Turvallinen lääkehoito - Opas lääkehoito- } \\
\text { suunnitelman tekemiseen sosiaali- ja terveydenhuollossa. THL Ohjaus 14/2015. }\end{array}$ \\
\hline & $\begin{array}{l}\text { Valviran ohje 3/2015. Hoitosuunnitelmat ja DNR-päätös pitkäaikaishoidossa sekä } \\
\text { ensihoito. }\end{array}$ \\
\hline & Valviran ohje: Liikkumista rajoittavien turvavälineiden käyttö. Päivitetty 27.1.2020. \\
\hline
\end{tabular}


Aineiston analyysi

Aineiston analyysimenetelmänä oli temaattinen analyysi. Tämä kuvaileva analyysimenetelmä valittiin, koska se sopii tekstimuotoisen aineiston laadulliseen analysointiin (Vaismoradi ym. 2013; Vaismoradi ym. 2016). Analyysi alkoi aineistoon tutustumisella sekä alustavien ajatusten muistiinmerkitsemisellä ja jatkui alustavalla aineiston koodaamisella. Kunkin koodin yhteyteen koottiin kyseisen koodin kannalta merkitykselliset tiedot. Tämän jälkeen koodatusta aineistosta etsittiin teemoja lajitellen koodit mahdollisten teemojen yhteyteen. Teemoja tarkasteltiin suhteessa koodattuihin otteisiin ja koko aineistoon ja lopuksi teemat nimettiin. (Braun \& Clarke 2006.)

\section{Tulokset}

Dokumenttianalyysin perusteella asukasturvallisuutta edistetään iäkkäiden tehostetussa palveluasumisessa: 1) omavalvonnalla ja omatoimisella varautumisella, 2) moniammatillisella yhteistyöllä sekä 3) lupa- ja valvontaviranomaisten toimilla ongelmatilanteissa. Pääteemat ja teemat on kuvattu taulukossa 2.

Tulosten mukaan iäkkäiden tehostetun palveluasumisen asukkaiden turvallisuuden edistämiseen osallistuu usea eri taho. Nämä tahot käyvät ilmi taulukosta 3. Osa toimista on lakisääteisiä, mutta mukana on myös suosituksia.

Omavalvonta ja omatoiminen varautuminen

\section{Omavalvontasuunnitelman laatiminen ja päivittäminen}

Omavalvonnalla pyritään varmistamaan, että toiminnassa toteutuvat lainsäädännön, lupaehtojen ja palvelujen tuottajan itse omalle toiminnalleen asettamat laatuvaatimukset (Valviran määräys 1/2014). Asumispalveluyksiköllä tulee olla Valviran määräyksen (1/2014) mukainen sosiaalihuollon palvelujen omavalvontasuunnitelma julkisesti nähtävänä. Suunnitelman toteutumista on seurattava ja päivittämisestä huolehdittava asianmukaisesti (Sosiaalihuoltolaki 1301/2014 § 47; Vanhuspalvelulaki 980/2012 $\S 23)$. Omavalvontasuunnitelman tulee kattaa koko yksikön toiminta. Siinä tulee kuvata esimerkiksi, miten riskinhallinta toteutetaan ja miten laatupoikkeamat ja vaaratilanteet käsitellään ja dokumentoidaan. Sosiaalihuollon palvelujen omavalvontasuunnitelma tulisi laatia yksikön johdon ja henkilökunnan yhteistyönä. Suunnitelman hyväksyy asumispalveluyksikön toiminnasta vastaava johtaja (Valviran määräys 1/2014.)

Taulukko 2. Asukasturvallisuuden edistäminen iäkkäiden asumispalveluyksiköissä.

\begin{tabular}{ll}
\hline Pääteema & Teema \\
Omavalvonta ja omatoiminen & Omavalvonnan suunnittelu \\
varautuminen & $\begin{array}{l}\text { Omavalvonnan toteuttaminen } \\
\text { Omatoiminen varautuminen }\end{array}$ \\
Moniammatillinen yhteistyö & $\begin{array}{l}\text { Yhteistyö terveydenhuollon ammattilaisten kanssa } \\
\text { Yhteistyö lupa- ja valvontaviranomaisten kanssa } \\
\text { Ilmoitus holhousviranomaiselle }\end{array}$ \\
& $\begin{array}{l}\text { Lupa- ja valvontaviranomaisten määräystenanto- ja } \\
\text { pakkokeinovaltuudet } \\
\text { Vupa- ja valvontaviranomaisten toimet } \\
\text { ongelmatilanteissa }\end{array}$ \\
&
\end{tabular}


Taulukko 3. läkkäiden tehostetun palveluasumisen asukkaiden turvallisuuden edistämisestä vastuussa olevat tahot.

\begin{tabular}{ll}
\hline Palveluntuottaja ja johto & Palveluntuottaja, toiminnanharjoittaja \\
& Työnantaja \\
& Yksikön johto \\
& Toimintayksikön vastuuhenkilö (yksikön toiminnasta vastaava \\
johtaja), esimies & \\
Asumispalveluyksikön & Työntekijä, henkilöstö \\
henkilöstö & \\
Terveydenhuollon & Yksikön vastuulääkäri, asiakkaiden lääketieteellisestä hoidosta \\
asiantuntijat & vastaava lääkäri (hoitava lääkäri) \\
& Tartuntataudeista vastaava lääkäri \\
& Muut terveydenhuollon asiantuntijat (esim. farmasian, \\
fysioterapian, toimintaterapian, ravitsemushoidon ja suun & terveydenhuollon asiantuntijat) \\
Rakennuksen ja kiinteistön & Rakennuksen omistaja \\
omistaja ja haltija & Kiinteistön omistaja \\
& Rakennuksen haltija \\
Kiinteistön haltija & Sosiaali- ja terveysalan lupa- ja valvontavirasto \\
Aluehallintovirastot \\
Kunnat (kuntayhtymät) \\
Terveydensuojeluviranomainen \\
Elintarvikevalvontaviranomainen \\
Pelastusviranomainen \\
\hline
\end{tabular}

Toimintaedellytysten varmistaminen yksikössä

Yksiköllä on oltava vastuuhenkilö, joka vastaa siitä, että palvelut täyttävät niille asetetut vaatimukset (Laki yksityisistä sosiaalipalveluista 922/2011 §5). Yksikössä tulee myös olla riittävät ja asianmukaiset toimitilat ja varusteet sekä toiminnan edellyttämä henkilöstö (Laki yksityisistä sosiaalipalveluista 922/2011 §4). Asuinolosuhteiden tulee olla sellaiset, ettei niistä aiheudu terveyshaittaa (Terveydensuojelulaki 763/1994 §26). Henkilöstön määrän, koulutuksen ja tehtävärakenteen tulee vastata toimintayksikön palveluja saavien iäkkäiden määrää ja heidän toimintakykynsä edellyttämää palvelun tarvetta (Vanhuspalvelulaki 980/2012 §20). Työvuorosuunnittelussa tulee varmistaa lääke- ja muun hoidon riittävä asiantuntemus jokaisessa työvuorossa (STM 2017).

Työnantajan tulee seurata sosiaali- ja terveydenhuollon ammattihenkilöiden ammatillista kehittymistä ja mahdollistaa osallistuminen esimerkiksi täydennyskoulutukseen sekä luoda edellytykset tarvittavalle perehdytykselle (Laki terveydenhuollon ammattihenkilöistä 559/1994 §18; Laki sosiaalihuollon ammattihenkilöistä 817/2015 §5). Työnantajan tulee myös varmistua siitä, että ammattihenkilön kielitaito on hänen tehtäviensä edellyttämällä riittävällä tasolla (Laki terveydenhuollon ammattihenkilöistä 559/1994 §18a). 


\section{Hoidon turvallisuuden varmistaminen}

Henkilöstön tulisi toimia asukasturvallisuutta vaarantamatta (STM 2017). Oireisena tai sairaana ei pitäisi tulla töihin ja suojavarusteita tulisi käyttää ohjeiden mukaisesti (STM ohje 15.5.2020). Hoitotyössä tulisi toimia rauhallisesti, kuten varata riittävästi aikaa avustettaessa asukasta ruokailussa tukehtumisvaaran välttämiseksi (VRN \& THL 2020). Asiakastyöhön osallistuva henkilöstö on myös velvollinen kirjaamaan sosiaalihuollon järjestämisen, suunnittelun, toteuttamisen, seurannan ja valvonnan kannalta tarpeelliset ja riittävät tiedot (Laki sosiaalihuollon asiakasasiakirjoista 254/2015 §4).

Lääkehoidon turvallisuus on osa asukasturvallisuutta asumispalveluyksikössä, ja lääkehoitoon liittyvät riskit tulisi pyrkiä tunnistamaan ja minimoimaan (Inkinen ym. 2015). Lääkkeiden säilytys ja käyttö tulisi ohjeistaa asianmukaisesti ja yksikössä tulisi olla toimintasuunnitelma lääkitysvirheiden varalta. Työyksikössä tulisi tunnistaa lääkehoitoon liittyvät osaamistarpeet sekä suunnitella, miten niihin vastataan. Lääkkeiden väärinkäyttöön tulee puuttua välittömästi. Lääkehoitoon osallistuvien osalta tulisi varmistua tarvittavista lääkeluvista. Sekä työntekijän että esimiehen tehtävänä on seurata lääkelupien voimassaoloa. Työntekijän tulisi toimia lääkehoitoa toteuttaessaan oman osaamisensa ja lääkelupansa rajoissa ja noudattaa työyksikön lääkehoitosuunnitelmaan kirjattuja ohjeita. Työnantajan tai esimiehen tehtävänä on arvioida lääkehoidon turvallista toteutumista ja puuttua tarvittaessa havaitsemiinsa epäkohtiin. (Inkinen ym. 2015.)

\section{Epäkohtailmoitusten ja palautteiden hyödyntäminen omavalvonnassa}

Asumispalveluyksikön henkilöstöllä on lakiin perustuva velvollisuus ilmoittaa viipymättä toiminnasta vastaavalle henkilölle, jos tehtävissään huomaa tai saa tietoonsa epäkohdan tai ilmeisen epäkohdan uhan asiakkaan sosiaalihuollon toteuttamisessa (Sosiaalihuoltolaki
1301/2014 §48). Ilmoituksen vastaanottajan on ilmoitettava asiasta kunnan sosiaalihuollon johtavalle viranhaltijalle ja käynnistettävä toimet epäkohdan tai ilmeisen epäkohdan uhan poistamiseksi. Asiasta on lisäksi ilmoitettava aluehallintovirastoon (AVI), jos epäkohtaa tai ilmeisen epäkohdan uhkaa ei korjata viivytyksettä. Palveluntuottajan on tiedotettava henkilöstölleen ilmoitusvelvollisuudesta ja sen toteuttamisesta, ja menettelyohjeet on sisällytettävä yksikön omavalvontasuunnitelmaan. (Sosiaalihuoltolaki 1301/2014 § 48-49.)

Toimintaa tulisi kehittää asiakkailta ja henkilöstöltä sännnöllisesti kerättävän palautteen perusteella (Sosiaalihuoltolaki 1301/2014 §47; Vanhuspalvelulaki 980/2012 §23). Asukkaalla tai tietyissä tapauksissa hänen laillisella edustajallaan, omaisella tai muulla läheisellä on myös oikeus tehdä sosiaali- ja terveydenhuollon palveluun tai kohteluun liittyvä muistutus (Sosiaalihuollon asiakaslaki 812/2000 §23). Muistutusoikeudesta on tiedotettava ja tehtävä muistutuksen tekeminen mahdollisimman vaivattomaksi. Toimintayksikön tai sosiaalihuollon johtavan viranhaltijan on annettava muistutukseen kirjallinen, perusteltu vastaus kohtuullisessa ajassa (Sosiaalihuollon asiakaslaki 812/2000 §23). Asiakkaalla tai omaisella on myös mahdollisuus tehdä kantelu valvontaviranomaiselle. Jos asiasta ei ole tehty muistutusta, asia voidaan kuitenkin siirtää asianomaiseen asumispalveluyksikköön tai sosiaalihuollon johtavan viranhaltijan käsiteltäväksi. (Sosiaalihuollon asiakaslaki 812/2000 §23a.)

\section{Laiteturvallisuuden varmistaminen}

Iäkkäiden asumispalveluyksiköissä on muun muassa sairauksien diagnostiikkaan ja hoitoon tarkoitettuja terveydenhuollon laitteita ja välineitä, joiden aiheuttamista vaaratilanteista käyttäjän on ilmoitettava sekä Lääkealan turvallisuus- ja kehittämiskeskukselle että laitteen valmistajalle tai edustajalle. Yksikön tulee huolehtia myös laitteiden rekisteröinnistä, niiden toimintakunnosta, käyttökoulutuksesta, 
käyttöohjeista ja tuotteiden jäljitettävyydestä (Laki terveydenhuollon laitteista ja tarvikkeista $629 / 2010$ § 5 ja 24-26). Omavalvontasuunnitelmaan on kirjattava laitteiden turvallisuusja vaaratilanneilmoituksista vastaavan henkilön yhteystiedot (Valviran määräys 1/2014). Robotisaation ja turvateknologian mahdollisuuksia suositellaan hyödynnettäväksi iäkkäiden palveluissa nykyistä enemmän asukasturvallisuuden edistämiseksi (STM 2017). Asumispalveluyksikön omavalvontasuunnitelmassa on kuvattava yksikössä käytössä olevat teknologiset ratkaisut sekä se, miten varmistetaan asiakkaiden käytössä olevien turva- ja kutsulaitteiden toimivuus ja hälytyksiin vastaaminen (Valviran määräys 1/2014).

\section{Tartuntatautien torjunta ja elintarviketurvallisuuden varmistaminen}

Osa asukasturvallisuutta on tartuntatautien torjunta. Sekä työntekijän että työantajan tulisi pyrkiä varmistamaan infektioiden leviämisen ehkäiseminen. Toimintayksiköiden asiakas- ja potilastiloissa, joissa hoidetaan lääketieteellisesti arvioituna tartuntatautien vakaville seuraamuksille alttiita asiakkaita tai potilaita, saa käyttää vain erityisestä syystä henkilöä,jolla on puutteellinen rokotussuoja (Tartuntatautilaki 1227/2016 §48). Lisäksi tartuntatautilain (1227/2016) 55 §:n mukaan työnantajan on tietyissä tilanteissa vaadittava työntekijältä, harjoittelijalta tai muilta vastaavilta henkilöiltä luotettava selvitys siitä, ettei hän sairasta hengitysteiden tuberkuloosia. Työnantajan on huolehdittava siitä, että henkilökunnalla on osaaminen infektioiden ehkäisy- ja torjuntakäytännöistä ja käytössään riittävä määrä suojavarusteita. Epidemian aikana tilojen desinfiointiin ja siivoukseen on kiinnitettävä erityistä huomiota. Lisäksi on suositeltavaa minimoida henkilökunnan vaihtuvuus sekä toteuttaa asukkaiden ja läheisten tapaamiset turvallisesti. (STM ohje 15.5.2020.)

Asumispalveluyksiköissä käsitellään elintarvikkeita,ja myös tähän liittyy omavalvonnan velvoite (Elintarvikelaki 23/20016, §19). Pakkaamattomia, helposti pilaantuvia elintarvikkeita asumispalveluyksikössä käsittelevällä henkilöstöllä on oltava elintarvikehygieenistä osaamista osoittava hygieniapassi (Elintarvikelaki 23/2006 §27). Lisäksi työnantajan on vaadittava työntekijältä luotettava selvitys siitä, ettei työntekijällä ole salmonellatartuntaa, jos henkilö on sellaisissa tehtävissä, joihin liittyy salmonellatartunnan tavallista suurempi leviämisvaara (Tartuntatautilaki 1227/2016 §56). Tämä selvitys tulee vaatia myös harjoittelijoilta ja muilta henkilöiltä, jotka toimivat työpaikalla ilman palvelussuhdetta. Työnantajan on vaadittava kyseinen salmonellaselvitys ennen palvelussuhteen alkamista tai silloin, kun työssä olon aikana on perusteltu syy epäillä, että henkilö on salmonellabakteerin kantaja.

\section{Pelastuslain mukainen varautuminen}

Pelastuslain (379/2011) 4 §:ään on kirjattu yleinen huolellisuusvelvollisuus, jonka mukaan"jokaisen on oltava huolellinen tulipalon tai muun onnettomuuden, vaaran ja vahingon välttämiseksi”. Pelastuslaki (379/2011 §14) velvoittaa asumispalveluyksiköitä omatoimiseen varautumiseen. Rakennuksen omistajan ja haltijan sekä toiminnanharjoittajan on ehkäistävä tulipalojen syttymistä ja muiden vaaratilanteiden syntymistä, varauduttava henkilöiden, omaisuuden ja ympäristön suojaamiseen vaaratilanteissa sekä varauduttava tulipalojen sammuttamiseen ja muihin sellaisiin pelastustoimenpiteisiin, joihin he omatoimisesti kykenevät. Lisäksi on ryhdyttävä toimenpiteisiin poistumisen turvaamiseksi tulipaloissa ja muissa vaaratilanteissa sekä toimenpiteisiin pelastustoiminnan helpottamiseksi. Pelastussuunnitelman laatimisesta vastaa rakennuksen tai kohteen haltija, ja se tulee laatia yhteistyössä asumispalveluyksikön toiminnanharjoittajan kanssa (Pelastuslaki 379/2011 §15).

Toiminnanharjoittajan velvollisuuksiin kuuluu poistumisturvallisuusselvityksen laatiminen (Pelastuslaki 379/2011 § 18 ja 19). On 
huolehdittava siitä, että asukkaat tai hoidettavat henkilöt voivat poistua turvallisesti tulipalossa tai muussa vaaratilanteessa itsenäisesti tai avustettuna. Toiminnanharjoittaja on velvollinen huolehtimaan siitä, että tilat varustetaan riittävällä määrällä laitteita, jotka havaitsevat alkavan tulipalon ja varoittavat siitä. Laitteiden (kuten sammutuskaluston) kunnossapidosta tulee myös huolehtia. (Pelastuslaki 379/2011 $\S 12, \S 17$.) Kiinteistön omistajan tai haltijan sekä toiminnanharjoittajan on huolehdittava siitä, että hälytysajoneuvoille tarkoitetut ajotiet ja pelastustiet pidetään ajokelpoisina ja esteettöminä ja merkitään asianmukaisesti (Pelastuslaki 379/2011 §11). Uloskäytävät ja kulkureitit niille tulee pitää kulkukelpoisina ja esteettöminä ja muutoinkin sellaisessa kunnossa, että niitä voidaan käyttää turvallisesti ja tehokkaasti. Lisäksi rakennus sekä sen ympäristö tulee pitää sellaisessa kunnossa, että tulipalon syttymisen, tahallisen sytyttämisen ja leviämisen vaara on vähäinen (Pelastuslaki 379/2011 §9-10.)

\section{Moniammatillinen yhteistyö}

\section{Yhteistyö lupa- ja valvontaviranomaisten kanssa}

Asukasturvallisuuden edistäminen iäkkäiden asumispalveluyksiköissä vaatii eri tahojen yhteistyötä. Yhteistyövelvoitteita ja suosituksia on kirjattu lakeihin, määräyksiin, suosituksiin ja ohjeisiin, niin asumisen kuin palveluidenkin turvallisuuden edistämiseksi. Yhteistyöhön velvoitetaan esimerkiksi ilmoitusvelvollisuuksien muodossa.

Yksityisen palvelutuottajan, joka tuottaa ympärivuorokautista asumispalvelua, on saatava lupa palvelujen tuottamiseen ennen toiminnan aloittamista ja olennaista muuttamista (Laki yksityisistä sosiaalipalveluista 922/2011 $\S 7)$. Lupahakemuksen johdosta AVI:n on tarkastettava toimintayksikkö. Tarkastukseen voi osallistua AVI:n pyynnöstä sen kunnan tai kuntayhtymän edustaja, jonka alueella palve- lua tullaan tuottamaan. Palveluntuottajan on tehtävä kirjallinen ilmoitus vastuuhenkilön vaihtumisesta ja toiminnan lopettamisesta luvan myöntäneelle lupaviranomaiselle sekä annettava toiminnastaan vuosittain kertomus lupaviranomaiselle (Laki yksityisistä sosiaalipalveluista 922/2011 §12 ja $§ 16)$.

Valvontaviranomaisten (AVI, Valvira, kunta/kuntayhtymä) on toteutettava valvontaa ensisijaisesti antamalla ohjausta ja neuvontaa palvelujen tuottajalle sekä seuraamalla toiminnan kehitystä yhteistyössä palvelujen tuottajan kanssa (Laki yksityisistä sosiaalipalveluista 922/2011 § 15). Valvontaviranomaisen tulee pyrkiä tukemaan palveluntuottajan omavalvontaa. Valvontaviranomainen voi vaatia sosiaalihuollon palvelujen omavalvontasuunnitelman täydentämistä, korjaamista tai muuttamista. Valvontaviranomaiset voivat tarkastaa palvelujen tuottajan toiminnan, toimintayksikön ja toimitilat, kun tarkastuksen tekemiseen on perusteltu syy. Tarkastus voidaan tehdä ennalta ilmoittamatta. (Laki yksityisistä sosiaalipalveluista 922/2011 §17-18.) Asiakas- ja potilasturvallisuutta pyritään edistämään myös sosiaali- ja terveydenhuollon ammattihenkilöiden ohjauksella ja valvonnalla. Valvira ylläpitää sosiaali- ja terveydenhuollon ammattihenkilöiden keskusrekistereitä, joiden tietopalvelusta voi tarkistaa sosiaali- ja terveydenhuollon ammattihenkilön ammattipätevyyden sekä tiedot ammatinharjoittamisoikeuden rajoittamisesta (Laki terveydenhuollon ammattihenkilöistä 559/1994 § 24 ja 24 a ja c; Laki sosiaalihuollon ammattihenkilöistä 817/2015 §15-16 ja 18).

Osassa kuntia ja kuntayhtymiä on käytössä palveluseteli iäkkäiden asumispalveluissa. Kunta tai kuntayhtymä hyväksyy ne palvelujentuottajat, joiden palvelujen maksamiseen asiakas voi käyttää palveluseteliä. Hyväksytyistä palvelujen tuottajista pidetään luetteloa. Kunnan tai kuntayhtymän on peruutettava palvelujen tuottajan hyväksyminen ja poistettava tuottaja luettelosta, jos hyväksymiselle asetetut edellytykset eivät enää täyty tai palvelujen tuottaja pyytää hyväksymisen peruuttamista (Laki 
sosiaali- ja terveydenhuollon palvelusetelistä 569/2009 §4). Kunnan palvelusetelituottajia koskevat hyväksymis- ja rekisteröintitehtävät rinnastuvat palveluntuottajien valvontaan ja ovat siten osa palvelujen laadun ja turvallisuuden edistämistä.

Asumisen turvallisuus edellyttää yhteistyötä palovaaran ja onnettomuuksien ehkäisemisessä. Viranomaisella on pelastuslain $42 \S: n$ mukaan velvollisuus ilmoittaa havaitsemastaan palo- tai onnettomuusvaarasta alueen pelastusviranomaiselle. Ilmoitusvelvollisuus koskee lisäksi kuntaa, muuta julkisyhteisöä ja niiden palveluksessa olevaa henkilöstöä sekä hoitolaitoksen ylläpidosta ja palvelu- ja tukiasumisen järjestämisestä huolehtivaa toiminnanharjoittajaa ja tämän palveluksessa olevaa henkilöstöä. Palotarkastuksessa valvotaan, että rakennuksen omistaja ja haltija sekä toiminnanharjoittaja ovat osaltaan huolehtineet tulipalojen ja muiden vaaratilanteiden ennaltaehkäisystä, varautuneet henkilöiden, omaisuuden ja ympäristön suojaamiseen vaaratilanteissa, varautuneet tulipalojen sammuttamiseen ja muihin omatoimisiin pelastustoimenpiteisiin, ryhtyneet toimenpiteisiin poistumisen turvaamiseksi tulipaloissa tai muissa vaaratilanteissa sekä pelastustoiminnan helpottamiseksi ja huolehtineet muistakin pelastuslain (379/2011) mukaisista velvoitteista.

Asumispalveluyksikkö tekee yhteistyötä myös terveydensuojeluviranomaisten ja elintarvikevalvonnan kanssa. Toiminnanharjoittajan on tehtävä ennen yksikön toiminnan aloittamista Terveydensuojelulain (763/1994) mukainen kirjallinen ilmoitus kunnan terveydensuojeluviranomaiselle. Elintarvikelain (23/2006) 53 §:n mukaan valvontaviranomaisen on tarvittaessa annettava elintarvikealan toimijalle ohjeita ja kehotuksia elintarvikemääräysten noudattamiseksi ja omavalvonnan toimivuuden varmistamiseksi.

Asukasturvallisuutta edistää osaltaan myös holhoustoimilain (442/1999) 91 §:n mukainen oikeus ilmoittaa edunvalvonnan tarpeesta olevasta henkilöstä.

\section{Yhteistyö terveydenhuollon asiantuntijoiden kanssa}

Asumispalveluyksiköt luetaan sosiaalihuollon yksiköiksi. Asukkailla on kuitenkin myös terveydenhuollon palvelujen tarvetta. On suositeltavaa hyödyntää esimerkiksi ravitsemus- ja puheterapeutin asiantuntemusta erityisosaamista vaativissa tilanteissa iäkkään ravitsemushoidon turvallisuuden edistämiseksi. Myös suun terveydenhuollon asiantuntijoiden, toimintaterapeutin tai fysioterapeutin asiantuntemuksen hyödyntämisen tulisi olla mahdollista. (VRN \& THL 2020.) Asumispalveluyksikön ja terveydenhuollon asiantuntijoiden yhteistyön merkitys korostuu etenkin tartuntatautien torjunnassa. Terveydenhuollon ja sosiaalihuollon toimintayksikön on torjuttava suunnitelmallisesti hoitoon liittyviä infektioita (Tartuntatautilaki 1227/2016 § 17). Yksikössä tulisi olla yhteyshenkilö, joka huolehtii tiedonkulusta paikallisten terveysviranomaisten ja alueellisten infektioasiantuntijoiden kanssa. Tartuntatautilain (1227/2016) säännöksiä henkilön eristämisestä tai määräämisestä karanteeniin voidaan säännösten soveltamisen edellytysten täyttyessä toteuttaa tartuntatautilain määräämällä tavalla iäkkäiden asumispalveluyksikössä (STM ohje VN/7643/2020).

Lääketieteellisen hoidon tarpeen arviointi ja diagnosointi tulisi toteuttaa asiamukaisesti, ja asukkaan lääkityksen asianmukaisuutta tulisi arvioida vähintään puolivuosittain (STM 2017). Lääkehoidon turvallisuutta tulee pyrkiä edistämään moniammatillisessa yhteistyössä. Asumisyksikön lääkehoidon kokonaisuudesta vastaa yksikön terveydenhuollosta tai lääketieteellisestä toiminnasta vastaava lääkäri,joka hyväksyy yksikön lääkehoitosuunnitelman. Asumispalveluyksikön johto kantaa kokonaisvastuun turvallisen lääkehoidon toteutumisesta ja edellytyksistä yksikössään. Johto käsittelee läheltä piti -tilanteet ja poikkeamat yhdessä henkilökunnan kanssa ja käynnistää tarvittavat korjaavat toimenpiteet. Yksikön lääkehoitosuunnitelmaa laadittaessa suositellaan hyödyn- 
tämään esimerkiksi farmasian asiantuntemusta. (Inkinen ym. 2015.) STM:n asumispalveluyksiköiden akuuttilääkevarastoa koskevan ohjeen (STM ohje VN/8243/2020) mukaan iäkkäiden asumispalveluyksiköissä voidaan ylläpitää suppeaa akuuttilääkevarastoa. Yksikön vastuulääkäri määrittää, mitä lääkkeitä se voi sisältää (ei suonensisäisesti tai lihakseen annosteltavia lääkkeitä). Asumispalveluyksiköitä kannustetaan tekemään tiivistä yhteistyötä paikallisen apteekin, sairaala-apteekin tai lääkekeskuksen kanssa muun muassa akuuttilääkevarastoon liittyen.

Hoitava lääkäri vastaa potilaslain (785/1992 § 4a) ja terveydenhuoltolain (1326/2010) mukaisen, sairaanhoidon perustana toimivan hoitosuunnitelman tekemisestä (Terveydenhuoltolaki 1326/2010 § 24). Hoitosuunnitelman tarkoituksena on koota hoitoa koskevat linjaukset, hoidon järjestäminen ja seuranta. Suunnitelmat tulee tehdä kaikille pitkäaikaishoidossa ja hoivan parissa oleville asukkaille yhteisymmärryksessä potilaan kanssa tai omaisten tai muiden läheisten kanssa, jos potilas ei ole kykenevä ymmärtämään asiaa (Valviran ohje 3/2015.) Liikkumisen rajoittaminen on hoitopäätös, josta tulisi keskustella asukkaan kanssa, tai jos hän ei pysty päättämään hoidostaan itse, hänen lähiomaistensa tai muiden läheisten kanssa. Hoitopäätöksistä vastaa hoitava lääkäri, mutta arvioinnissa on syytä käyttää asukkaan ja hoitopaikan olosuhteet tuntevan hoitajan asiantuntemusta. Mahdollisia liikkumista rajoittavia välineitä tulee käyttää käyttöohjeiden mukaisesti ja vain niin kauan, kuin se on tarpeen. Vaikka lupa rajoittamistoimenpiteen käyttöön olisi, tulee käytön tarvetta harkita jokaisella käyttökerralla. (Valviran ohje 2020.) Perustuslain (731/1999) 7 §:n 1 momentin mukaan jokaisella on oikeus elämään sekä henkilökohtaiseen vapauteen, koskemattomuuteen ja turvallisuuteen. Tämänhetkinen sääntely itsemääräämisoikeuden toteuttamisesta sosiaalihuollossa on osin puutteellinen; esimerkiksi säännökset muistisairaiden hoitoon liittyvistä rajoitustoimenpiteistä puuttuvat (STM ohje $\mathrm{VN} / 7643 / 2020$ ).

Lupa- ja valvontaviranomaisten toimet
ongelmatilanteissa

\section{Lupa- ja valvontaviranomaisten määräystenanto- ja pakkokeinovaltuudet}

Valvontaviranomaisten on toteutettava asumispalveluyksiköiden valvontaa ensisijaisesti antamalla palvelujen tuottamisessa tarpeellista ohjausta ja neuvontaa, seuraamalla toiminnan kehitystä yhteistyössä palvelun tuottajan kanssa sekä edistämällä ja varmistamalla omavalvontaa. Valvontaviranomaisen on kuitenkin puututtava toimintayksikön toimintaan omavalvonnan pettäessä. Lupa- ja valvontaviranomaisilla on useita keinoja (kuten korjausmääräys, uhkasakko ja toiminnan keskeyttäminen) tällaisissa ongelmatilanteissa. Lisäksi Valviralla on oikeus tietyissä tapauksissa puuttua ammattihenkilön ammatinharjoittamiseen.

Terveydensuojeluviranomaisella on oikeus tehdä tarkastuksia terveydensuojelulain mukaisten tehtävien suorittamiseksi sekä teettää tarkastuksiin liittyviä tutkimuksia (Terveydensuojelulaki 763/1994 § 45). Jos asunnossa tai muussa oleskelutilassa havaitaan terveyshaittaa, voi terveydensuojeluviranomainen velvoittaa sen, jonka vastuulla haitta on, ryhtymään viipymättä tarvittaviin toimenpiteisiin terveyshaitan ja siihen johtaneiden tekijöiden selvittämiseksi, poistamiseksi tai rajoittamiseksi. Terveydensuojeluviranomainen voi kieltää tai rajoittaa asunnon tai muun oleskelutilan käyttöä,jos terveyshaitta on ilmeinen ja on syytä epäillä sen aiheuttavan välitöntä vaaraa, jos haittaa ei voida korjata tai jos terveydensuojeluviranomaisen määräystä haitan poistamiseksi ei ole noudatettu, eikä muita terveydensuojelulain mukaisia toimenpiteitä ole pidettävä riittävinä. (Terveydensuojelulaki 763/1994 27 §.)

Elintarvikevalvontaviranomaiset tekevät elintarvikelain (23/2006) mukaisia tarkastus- 
käyntejä arvioiden keittiöiden ja muiden elintarvikealan yritysten elintarviketurvallisuutta. Mahdollinen havaittu epäkohta vaatii korjaavia toimenpiteitä. Valvontatoimenpiteenä voidaan käyttää korjauskehotusta määräaikoineen tai elintarvikelain (23/206) mukaisia hallinnollisia pakkokeinoja. Pelastusviranomainen puolestaan voi tietyissä tilanteissa käyttää pelastuslain (379/2011) mukaisia pakkokeinoja, mikäli annettuja määräyksiä on laiminlyöty.

Lupaviranomainen (AVI, Valvira) voi antaa määräyksen puutteiden tai epäkohtien poistamiseksi havaitessaan lainvastaista menettelyä, asiakasturvallisuutta vaarantavia puutteita tai muita epäkohtia asumispalveluyksikössä. Määräystä voidaan tehostaa uhkasakolla. Mikäli toimintaa ei korjata asianmukaiseksi annetun määräajan kuluessa, voidaan toiminta keskeyttää tai kieltää. Lupaviranomainen voi myös tietyissä tilanteissa peruuttaa sosiaalipalvelujen tuottamiseen myöntämänsä luvan osittain tai kokonaan. (Laki yksityisistä sosiaalipalveluista 922/2011 §20-23.)

\section{Valviran puuttuminen ammatinharjoittamiseen}

Jos on perusteltua aihetta olettaa, että sosiaalitai terveydenhuollon ammattihenkilö ei sairauden, päihteiden väärinkäytön, heikentyneen toimintakyvyn tai muun vastaavan syyn takia kykene toimimaan ammatissaan, voi Valvira velvoittaa henkilön lääkärintarkastukseen tai sairaalatutkimuksiin. Valvira voi myös tarvittaessa määrätä sosiaali- ja terveydenhuollon ammattihenkilön ammatilliset tiedot ja taidot selvitettäväksi. Mikäli ammattihenkilö ei suostu ammatillisen toimintakyvyn ja terveyden tai ammattitaidon selvittämiseen, Valvira voi kieltää häntä harjoittamasta ammattiaan tai käyttämästä ammattinimikettään. (Laki terveydenhuollon ammattihenkilöistä 559/1994 § 25; Laki sosiaalihuollon ammattihenkilöistä 817/2015 § 19.) Ammattitietojen ja -taitojen selvittäminen liittyy terveydenhuollon ammattihenkilöiden jälkikäteiseen valvontaan ja on siten eri asia kuin lupahallinnon menettely, jota noudatetaan ammattihenkilön ammatillisia taitoja ensi kertaa arvioitaessa esimerkiksi laillistusta tai ammatinharjoittamislupaa myönnettäessä.

Valvira voi muun muassa rajoittaa laillistetun ammattihenkilön ammatinharjoittamisoikeutta tai poistaa sen, kieltää nimikesuojattua ammattihenkilöä käyttämästä asetuksella säädettyä ammattihenkilön ammattinimikettä tai peruuttaa luvan saaneen terveydenhuollon ammattihenkilön ammatinharjoittamisoikeuden. Valvira voi myös antaa ammattihenkilölle kirjallisen varoituksen. (Laki terveydenhuollon ammattihenkilöistä 559/1994 §26, 28 ja 33; Laki sosiaalihuollon ammattihenkilöistä $817 / 2015$ §20 ja 25.)

\section{Pohdinta}

Tämä artikkeli tarjoaa kokonaiskuvan asukasturvallisuuden edistämisestä iäkkäille tehostettua palveluasumista tarjoavissa asumispalveluyksiköissä Suomessa. Asukasturvallisuuden edistämisen vastuiden ja velvollisuuksien tiedostaminen on tarpeellista asumispalveluyksiköissä työskenteleville, yksiköiden vastuuhenkilöille, työnantajille, palveluntuottajille sekä muille iäkkäiden asukasturvallisuuden edistämiseen osallistuville tahoille. Tämän dokumenttianalyysin mukaan asukasturvallisuuden edistäminen iäkkäiden tehostetussa palveluasumisessa vaatii monen tahon asiantuntemusta ja yhteistyötä. Erityinen vastuu asukasturvallisuudesta on toimintayksikön johdolla, mutta asukasturvallisuustyö kuuluu kaikille yksikössä työskenteleville. Asukasturvallisuuteen pyritään ensisijaisesti yksikön omatoimisella varautumisella ja omavalvonnalla, jota valvontaviranomaisten tulee tukea. Omavalvonnan pettäessä ja asukasturvallisuuden vaarantuessa on lupa- ja valvontaviranomaisilla kuitenkin monia keinoja puuttua tilanteeseen.

Tutkimuksessa esille nousseen valvonnan ja omavalvonnan vaikuttavuudesta on melko vä- 
hän tietoa (Nykänen ym.2017). Omavalvonnan tulisi kuitenkin olla osa asumispalveluyksiköiden normaalia toimintaa (STM 2020b). EteläSuomen aluehallintoviraston tekemän selvityksen mukaan asumispalveluyksiköissä noudatetaan hyvin vaatimusta laatia sosiaalihuollon palvelujen omavalvontasuunnitelma, mutta suunnitelmien sisällöissä on puutteita (Vehkaoja \& Vainio 2017). Yksikön omavalvontasuunnitelman ei tulisi jäädä palvelujen kuvaukseksi, vaan siitä tulisi käydä ilmi, miten palvelujen laatu ja turvallisuus varmistetaan (Valviran määräys 1/2014). Suunnitelmassa tulisi esimerkiksi kuvata hoito- ja palvelusuunnitelmien laatimisprosessi mutta myös se, miten varmistetaan, että suunnitelmat ovat ajan tasalla ja henkilökunta toimii niiden mukaisesti (Vehkaoja \& Vainio 2017). Omavalvontaan liittyen tärkeää olisi avoin ja luottamuksellinen ilmapiiri yksikössä. Aiempi tutkimus on osoittanut, että kun virheistä ei syyllistetä, niitä uskalletaan tuoda paremmin esille (Kinnunen 2010).

Dokumenttianalyysissä tuli esille vaatimus riskinhallinnasta osana omavalvontaa ja sen suunnittelua. Riskienhallinta edellyttää varautumista muun muassa mahdollisiin häiriö- ja poikkeustilanteisiin (STM 2011; Saarsalmi \& Koivula 2017). Palveluntuottajalla olisi hyvä olla suunnitelma siitä, miten yksikössä toimitaan esimerkiksi sähkö- tai vesikatkoksen aikana (Vehkaoja \& Vainio 2017). Aiempien tutkimusten ja selvitysten mukaan iäkkäiden palvelujen omatoimisessa varautumisessa on vielä kehitettävää (Ung-Lanki ym. 2017; Vehkaoja \& Vainio 2017).

Henkilöstön riittävän osaamisen ja määrän varmistaminen on osa asukasturvallisuuden edistämistä. Aiemman tutkimuksen mukaan henkilöstön osaamisen vajeet ovat yksi asukasturvallisuutta vaarantaviin tapahtumiin myötävaikuttava tekijä (Andersson ym. 2018). Suomessa iäkkäiden asumispalveluyksiköissä työskentelevien hoitotyön ammattilaisten itsearvioinnin mukaan kehittämistä vaatii kyky ennaltaehkäistä vaaratilanteita ja tapaturmia (Kiljunen 2019). Henkilöstön osaamiseen ja määrään liittyy myös kysymys osaamisen hyödyntämisestä. Suomessa iäkkäiden asumispalveluyksiköissä osalla hoitohenkilökuntaa työnkuvaan kuuluu jonkin verran tukipalvelutehtäviä (kuten siivousta, pyykkihuoltoa, keittiötyötä), ja kuitenkin hoitajien odotetaan olevan valppaana asukkaiden turvallisuuden suhteen koko ajan (Kiljunen ym. 2018). Vanhuspalvelulain (980/2012) 1.10.2020 voimaan tulleilla säännöksillä pyritään turvaamaan hoitohenkilökunnan keskittyminen välittömään asiakastyöhön.

Asukasturvallisuuden edistäminen edellyttää myös lääketieteellisen ja muun terveydenhuollon asiantuntemuksen hyödyntämistä ja moniammatillista yhteistyötä. Esimerkiksi yksikön lääkehoidosta vastaavan lääkärin rooli turvallisessa lääkehoidossa nousi esille tuloksissa. Valviran ja AVI:en valvontahavaintojen perusteella iäkkäiden asumispalveluyksiköissä on ollut puutteita terveydenhuoltopalvelujen järjestämisessä. Esimerkiksi osassa iäkkäiden asumispalveluyksiköitä käy lääkäri paikan päällä vain harvoin (Valvira 2020b). Kuitenkin yksikön lääkehoidosta vastaavalla lääkärillä tulisi olla tietoa yksikön asukkaiden lääkehoidon tarpeista ja lääkehoidon kokonaisuudesta (Inkinen ym. 2015).

Asumispalveluyksiköissä tehdään yhteistyötä myös lupa- ja valvontaviranomaisten kanssa. Dokumenttianalyysimme tuloksissa painottuu AVI:n ja Valviran rooli asukasturvallisuuden edistämisessä, vaikka sosiaalihuollon palvelujen ensisijaisena valvojana toimivat kunnat ja kuntayhtymät (Valvira 2020b). Kuten tutkimuksessa kävi ilmi, myös ammattihenkilövalvonnalla pyritään asukasturvallisuuden varmistamiseen. Ensisijaisesti on työnantajan vastuulla huolehtia mahdolliseen epäasialliseen ammattitoimintaan puuttumisesta. On tärkeää, että henkilökunta tietää, kuinka toimia esimerkiksi asukkaiden kaltoinkohtelua havaitessaan (Sipiläinen 2016). Joskus työnantajan toimet eivät kuitenkaan riitä. Työnantaja voi tehdä rikosilmoituksen poliisille tai ilmoittaa asukasturvallisuuden vaarantumisesta Valviraan tai 
aluehallintovirastolle, kun kyseessä on sosiaalija/tai terveydenhuollon ammattihenkilö. Ammatinharjoittamisoikeuden rajoituksilla ja/tai poistoilla pyritään ehkäisemään asukkaiden hoidon vaarantuminen. Tutkimustietoa näistä toimista on kuitenkin vielä rajoitetusti saatavilla (Papinaho ym. 2019).

Dokumenttianalyysin tekemisen aikaan oli voimassa asumispalveluyksiköitä koskevia koronavirustaudin ehkäisemisen ohjeita, ja tuloksissa tuli vahvasti esille infektioiden torjunta osana asukasturvallisuuden edistämistä. Koronaviruspandemia teki näkyväksi asukasturvallisuuden edistämistä koskevien toimien haasteellisuuden iäkkäiden tehostetussa palveluasumisessa. Koronapandemian myötä omaisten sekä muiden vierailijoiden mahdollisuutta vierailla yksiköissä rajoitettiin eri tahojen ohjeistusten perusteella. Myöhemmin eduskunnan apulaisoikeusasiamies toi esille, että vierailuja oli kielletty tai rajoitettu osin lainvastaisesti (EOAK 3232/2020). Apulaisoikeusasiamies totesi, että kontaktien vähentämisellä oli merkittävä vaikutus sairastavuuden ja sitä kautta kuolleisuuden vähentämisessä, ja voidaan arvioida, että ainakin osittainen rajoittaminen olisi vastaavassa tilanteessa jatkossakin välttämätöntä elämän suojelemiseksi. Vierailukieltoja asetettaessa olisi tullut kuitenkin arvioida välttämättömyyttä ja oikeasuhtaisuutta sekä vaihtoehtoisia keinoja viruksen leviämisen estämiseksi. Näissä yksiköissä joudutaan usein muissakin tilanteissa tasapainottelemaan asukkaan itsemääräämisoikeuden tukemisen ja turvallisuuden edistämisen välillä (Evans ym. 2018).

Teknologian merkitys asukasturvallisuuden edistämisessä jää tämän dokumenttianalyysin tuloksissa melko näkymättömäksi. Esimerkiksi lääkitysturvallisuutta edistetään teknologisilla ratkaisuilla, kuten koneellisella annosjakelulla (Inkinen ym. 2015). Lisäksi lääkkeenmääräämisen sekä lääkehoidon riskienarvioinnin tukena käytetään riskienhallintatyökaluja, kuten yhteisvaikutustietokantoja ja tietokantoja iäkkäille sopivista lääkkeistä (STM 2018). Tutkimuksessa rajattiin aineisto lakeihin, oh- jeisiin ja määräyksiin, jotka velvoittavat suoraan tehostetun palveluasumisen yksiköitä. Ulkopuolelle jäävät tässä dokumenttianalyysissä lait, jotka eivät suoraan velvoita asumispalveluyksiköitä (kuten lääkelaki) mutta edesauttavat asukasturvallisuutta. Asukasturvallisuuden edistämisen tarkastelu laki- ja muiden vastaavien tekstien pohjalta tarjoaa kuitenkin yhden lähestymistavan ilmiön tarkastelulle.

Tässä tutkimuksessa tarkasteltiin asukasturvallisuuden edistämistä lakeihin sekä valtakunnallisiin määräyksiin, suosituksiin ja ohjeisiin rajoittuvan aineiston pohjalta. Tämäntyyppisessä aineistossa korostuu fyysisen turvallisuuden edistäminen; asukasturvallisuus sisältää kuitenkin myös muita aspekteja. Tutkimuksessa hyödynnetyt dokumentit on alunperin luotu muuhun kuin tutkimustarkoitukseen, eivätkä ne siten tarjoa kaikilta osin yksityiskohtaista tietoa tarkasteltavasta ilmiöstä (Bowen 2009). Hoitotyön arjen kuvaamiseksi ja selvittämiseksi tarvitaan muita tutkimusmenetelmiä.

\section{Johtopäätökset}

Asukasturvallisuuden edistäminen iäkkäiden tehostetussa palveluasumisessa vaatii moniammatillista yhteistyötä. Riittävän lääketieteellisen ja muun terveydenhuollon ammattilaisten asiantuntemuksen tulisi olla osa asukkaiden hoitoa. Lisäksi toiminnan kehittämisessä voidaan hyödyntää omaisilta ja asukkailta saatavaa palautetta ja havaintoja. On tärkeää, että henkilöt ja tahot, jotka ovat vastuussa asukasturvallisuudesta, tiedostavat vastuunsa ja pyrkivät käytännössä omalta osaltaan edistämään turvallisuutta. Asukasturvallisuuden edistämiseen osallistuvilla valvontaviranomaisilla tulisi olla riittävästi aikaa hoitaa tehtäviään laadukkaasti. Iäkkäiden asumispalveluyksikön johto vastaa ensisijaisesti asukasturvallisuudesta yksikössä. Onkin olennaista huolehtia, että lähijohtajilla ja muulla johdolla on riittävästi osaamista laadun ja turvallisuuden johtamisesta. Yksikön 
vastaavalla on hyvä olla myös riittävästi aikaa asukasturvallisuustyöhön, kuten omavalvonnan suunnitteluun ja seurantaan. Lisäksi henkilöstöllä tulisi olla aito mahdollisuus osallistua asukasturvallisuuden kehittämiseen.

\section{Yhteydenotto:}

Outi Kiljunen, $\mathrm{Tt} T$, post doc -tutkija

Hoitotieteen laitos

Terveystieteiden tiedekunta

Itä-Suomen yliopisto

okiljune@uef.fi

\section{Kirjallisuus}

Alzheimer Europe. Dementia in Europe yearbook 2017: standards for residential care facilities in Europe. 2018. Internet: https://www.alzheimer-europe.org/Publications/Dementia-in-Europe-Yearbooks (viitattu 7.9.2020).

Andersson Å, Frank C, Willman AML, Sandman PO, Hansebo G. Factors contributing to serious adverse events in nursing homes. J Clin Nurs 2018;27(1-2):e354-62.

https://doi.org/10.1111/jocn.13914

Anttonen A, Karsio O. Eldercare service redesign in Finland: deinstitutionalization of long-term care. J Soc Serv Res 2016;42(2):151-66. https://doi.org/10.1080/01488376.2015.1129017

Bowen GA. Document analysis as a qualitative research method. Qual Res 2009;9(2):27-40. https://doi.org/10.3316/QRJ0902027

Braun V, Clarke V. Using thematic analysis in psychology. Qual Res Psychol 2006;3(2):77-101. https://doi.org/10.1191/1478088706qp063oa

Elintarvikelaki 23/2006. Internet: https://finlex.fi/fi/laki/ajantasa/2006/20060023 (viitattu 10.9.2020).*

EOAK 3232/2020. Apulaisoikeusasiamiehen päätös 18.6.2020. Vanhuksiin kohdistuvat rajoitukset koronaepidemian aikana. Internet: https://www.oikeusasiamies.fi/r/fi/ratkaisut/-/ eoar/3232/2020 (viitattu 3.8.2020).

Etelä-Suomen aluehallintovirasto/Aluehallintovirastojen hallinto- ja kehittämispalvelut. Tilinpäätös 2019, Etelä-Suomen aluehallintovirasto, kirjanpitoyksikkö. Aluehallintovirastojen julkaisuja 82/2020. Internet: https://www.avi.fi/
documents/10191/15743513/Julkaisu-82_Tilinpaatos-2019/4e4e53c1-a4ad-4447-83f2-ebf7ac65f713 (viitattu 25.6.2020).

Evans EA, Perkins E, Clarke P, Haines A, Baldwin A, Whittington R. Care home manager attitudes to balancing risk and autonomy for residents with dementia. Aging Ment Health 2018;22(2):2619. https://doi.org/10.1080/13607863.2016.124 4803

Gartshore E, Waring J, Timmons S. Patient safety culture in care homes for older people: a scoping review. BMC Health Services Research 2017;17:752.

https://doi.org/10.1186/s12913-017-2713-2

Holhoustoimilaki 1999/442. Laki holhoustoimesta. Internet: https://www.finlex.fi/fi/laki/ajantasa/1999/19990442 (viitattu 8.9.2020).*

Inkinen R, Volmanen P, Hakoinen S, toim. Turvallinen lääkehoito - opas lääkehoitosuunnitelman tekemiseen sosiaali- ja terveydenhuollossa. THL, Ohjaus 14/2015.*

Kiljunen O. Care home nursing professionals' competence in older people nursing. Itä-Suomen yliopisto, terveystieteiden tiedekunta, hoitotieteen laitos. Publications of the University of Eastern Finland, Dissertations in Health Sciences, no 492. 2019. Internet: https://epublications.uef.fi/pub/ urn_isbn_978-952-61-2949-5/urn_isbn_978952-61-2949-5.pdf (viitattu 25.6.2020).

Kiljunen O, Kankkunen P, Partanen P, Välimäki T. Family members' expectations regarding nurses' competence in care homes: a qualitative interview study. Scand J Caring Sci 2018;32(3):101826. https://doi.org/10.1111/scs.12544

Kinnunen M. Virheistä oppimisen esteet ja mahdollistajat organisaatiossa. Vaasan yliopisto. Acta Wasaensia, 230.2010. Internet: https://www.univaasa.fi/materiaali/pdf/isbn_978-952-476-3233.pdf (viitattu 25.6.2020).

Laki sosiaalihuollon ammattihenkilöistä 817/2015. Internet: https://www.finlex.fi/fi/laki/ajantasa/2015/20150817 (viitattu 12.9.2020).*

Laki sosiaalihuollon asiakasasiakirjoista 254/2015. Internet: https://finlex.fi/fi/laki/alkup/2015/20150254 (viitattu 12.9.2020).*

Laki sosiaali- ja terveydenhuollon palvelusetelistä 569/2009. Internet: https://www.finlex.fi/fi/laki/ ajantasa/2009/20090569 (viitattu 12.9.2020).*

Laki terveydenhuollon ammattihenkilöistä 559/1994. Internet: https://www.finlex.fi/fi/laki/ajantasa/1994/19940559 (viitattu 12.9.2020).* 
Laki terveydenhuollon laitteista ja tarvikkeista 629/2010. Internet: https://finlex.fi/fi/laki/alkup/2010/20100629 (viitattu 10.9.2020).*

Laki yksityisistä sosiaalipalveluista 922/2011. Internet: https://www.finlex.fi/fi/laki/alkup/2011/20110922 (viitattu 11.9.2020).*

Noro A, Alastalo H, toim. Vanhuspalvelulain 980/ 2012 toimeenpanon seuranta: tilanne ennen lain voimaantuloa vuonna 2013. THL Raportti 13/2014. Internet:

http://www.julkari.fi/bitstream/handle/10024/116151/URN_ISBN_978-952-302169-3.pdf (viitattu 11.9.2020).

Nykänen E, Kovasin M, Liukko E, Blomqvist P, Krohn M, Ahola S ym. Vaikuttava valvonta osana sosiaali- ja terveydenhuollon uudistusta. Valtioneuvoston selvitys- ja tutkimustoiminnan julkaisusarja 29/2017.

Papinaho O, Häggman-Laitila A, Liedenpohja AM, Kangasniemi M. Integrative review of studies about nurses who have been disciplined by their professional regulatory bodies. J Nurs Manag 2019;27(8):1588-603. https://doi.org/10.1111/jonm.12883

Pelastuslaki 379/2011. Internet: https://finlex.fi/fi/laki/ajantasa/2011/20110379 (viitattu 12.9.2020).*

Potilaslaki 1992/785. Laki potilaan asemasta ja oikeuksista. Internet: https://finlex.fi/fi/laki/ajantasa/1992/19920785 (viitattu 12.9.2020).*

Saarsalmi O, Koivula R, toim. Näkökulmia sosiaalihuollon palvelujen turvallisuuteen. THL Ohjaus 19/2016, 2.versio/2017.33. 2017. Internet: http://www.julkari.fi/handle/10024/134849 (viitattu 25.6.2020).

Sipiläinen H. Hoitohenkilökunnan käsityksiä vanhusten kaltoinkohtelusta ympärivuorokautisen hoidon yksiköissä. Itä-Suomen yliopisto, terveystieteiden tiedekunta, hoitotieteen laitos. Publications of the University of Eastern Finland. Dissertations in Health Sciences, no 354. 2016. Internet: https://epublications.uef.fi/pub/urn isbn_978-952-61-2132-1/urn_isbn_978-95261-2132-1.pdf (viitattu 25.6.2020).

Sosiaalihuollon asiakaslaki 812/2000. Laki sosiaalihuollon asiakkaan asemasta ja oikeuksista. Internet: https://finlex.fi/fi/laki/ajantasa/2000/20000812 (viitattu 12.9.2020).*
Sosiaalihuoltolaki 1301/2014. Internet: https://www.finlex.fi/fi/laki/alku$\mathrm{p} / 2014 / 20141301 \#$ Pidp447022784 (viitattu 12.9.2020).*

STM. Riskienhallinta ja turvallisuussuunnittelu: Opas sosiaali- ja terveydenhuollon johdolle ja turvallisuussuunnittelijoille. Sosiaali- ja terveysministeriön julkaisuja 2011:15. Internet: http:// julkaisut.valtioneuvosto.fi/handle/10024/72811 (viitattu 25.6.2020).

STM. Laatusuositus hyvän ikääntymisen turvaamiseksi ja palvelujen parantamiseksi 2017-2019. STM julkaisuja 2017:6. Internet: http://julkaisut.valtioneuvosto.fi/handle/10024/80132 (viitattu 25.6.2020).*

STM. Tutkimustieto hyötykäyttöön: rationaalisen lääkehoidon tutkimusstrategia 2018-2022. Sosiaali- ja terveysministeriön raportteja ja muistioita 7/2018. Internet: https://stm.fi/julkaisu?pubid=URN:ISBN:978-952-00-3905-9 (viitat tu 5.9.2020).

STM. Potilas- ja asiakasturvallisuusstrategia 20172021: toimeenpanosuunnitelma. Sosiaali- ja terveysministeriön julkaisuja 2020:1.2020a.

STM. Laatusuositus hyvän ikääntymisen turvaamiseksi ja palvelujen parantamiseksi 2020-2023: tavoitteena ikäystävällinen Suomi. Sosiaali- ja terveysministeriön julkaisuja 2020:29. 2020b.

STM ohje VN/8243/2020. Covid-19 aiheuttaman poikkeustilan huomioiminen sosiaalihuollon asumispalveluyksiköiden lääkehuollossa. Internet:

https://stm.fi/documents/1271139/21429433/

STM+ohje+sosiaalihuollolle+rajatut+1\%C3\%A4\%C3\%A4kevarastot.pdf/504f38de-4a3e-d215-aae1-fa7bb259c4eb/STM+ohje+sosiaalihuollolle+rajatut $+1 \% \mathrm{C} 3 \% \mathrm{~A} 4 \% \mathrm{C} 3 \% \mathrm{~A} 4$ kevarastot.pdf (viitattu 2020).*

STM ohje VN/7643/2020. Tartuntatautilain ja valmiuslain vaikutus liikkumisvapauteen sosiaalihuollon yksiköissä. Internet: https://stm.fi/-/ stm-liikkumisvapautta-sosiaalihuollon-toimintayksikoissa-voidaan-rajoittaa-tarvittaessa (viitattu 2020).*

STM ohje 15.5.2020. Koronavirustartuntojen ehkäisy ympärivuorokautisen hoidon ja huolenpidon toimintayksiköissä. Internet: https://stm.fi/-/ 
stm-paivitti-ohjetta-koronavirustartunnan-ehkaisysta-ymparivuorokautisen-hoidon-toimintayksikoissa-toimintakykya-ja-yhteydenpitoa-laheisiin-tuetaan-my (viitattu 24.6.2020).*

Suomen perustuslaki 731/1999. Internet: https://www.finlex.fi/fi/laki/ajantasa/1999/19990731 (viitattu 12.9.2020).*

Tartuntatautilaki 1227/2016. Internet: https://www.finlex.fi/fi/laki/ajantasa/2016/20161227 (viitattu 13.9.2020).*

Terveydenhuoltolaki 1326/2010. Internet: https:// www.finlex.fi/fi/laki/ajantasa/2010/20101326 (viitattu 11.9.2020).*

Terveydensuojelulaki 763/1994. Internet: https:// www.finlex.fi/fi/laki/ajantasa/1994/19940763 (viitattu 11.9.2020).*

THL. Kotihoito ja sosiaalihuollon laitos- ja asumispalvelut 2018. Tilastoraportti 41/2019.

Internet: http://www.julkari.fi/bitstream/handle/10024/138808/Tr41_19.pdf?sequence $=5 \&$ isAllowed=y (viitattu 25.6.2020).

Ung-Lanki S, Vartiainen AK, Kollanus V, Lanki T. Helle terveysriskinä: varautuminen ja riskinhallinta hoitolaitoksissa ja kotihoidossa. Gerontologia 2017;31(2):100-15.

Internet: https://journal.fi/gerontologia/article/ view/64223/26240 (viitattu 25.6.2020).

Vaismoradi M, Jones J, Turunen H, Snelgrove S. Theme development in qualitative content analysis and thematic analysis. J Nurs Educ Pract 2016;6(5):100-10.

https://doi.org/10.5430/jnep.v6n5p100

Vaismoradi M, Turunen H, Bondas T. Content analysis and thematic analysis: implications for conducting a qualitative descriptive study. Nurs Health Sci 2013;15(3):398-405. https://doi.org/10.1111/nhs.12048

Valvira. Sosiaali- ja terveysalan lupa- ja valvontaviraston tilinpäätös vuodelta 2019.2020a. Internet: https:/www.valvira.fi/documents/14444/398591/Valvira_toimintakertomus_2019.pdf/3e9cb957-c8ca-06d5-a2248900c1a170ea?t=1582717003311 (viitattu 12.9.2020).
Valvira. Sosiaali- ja terveydenhuollon valtakunnallinen valvontaohjelma vuosille 2020-2023. 2020b. Internet: https://www.valvira.fi/documents/14444/1006217/Sosiaali_ja_terveydenhuollon_valtakunnallinen_valvontaohjelma_2020_2023.pdf/25bf2713-b705-e1248ab6-411a92424d4b?t=1583908687387 (viitattu 25.6.2020).

Valviran määräys 1/2014. Yksityisten sosiaalipalvelujen ja julkisten vanhuspalvelujen omavalvontasuunnitelman sisältöä, laatimista ja seurantaa koskeva määräys.

Internet: https://www.valvira.fi/-/maarays-1-2014-yksityisten-sosiaalipalvelujen-ja-julkisten-vanhuspalveluiden-omavalvontasuunnitelmasta (viitattu 12.9.2020).*

Valviran ohje 3/2015. Hoitosuunnitelmat ja DNRpäätös pitkäaikaishoidossa sekä ensihoito.

Valviran ohje: Liikkumista rajoittavien turvavälineiden käyttö. Päivitetty 27.1.2020.

Internet: https://www.valvira.fi/terveydenhuolto/potilaan-asema-ja-oikeudet-oikeudet/liikkumista_rajoittavien_turvavalineiden_kaytto (viitattu 10.9.2020).*

Vanhuspalvelulaki 980/2012. Laki ikääntyneen väestön toimintakyvyn tukemisesta sekä iäkkäiden sosiaali- ja terveyspalveluista.

Internet: https://www.finlex.fi/fi/laki/ajantasa/2012/20120980 (viitattu 12.9.2020).*

Vehkaoja P, Vainio P. Omavalvonta ympärivuorokautisessa vanhustenhuollossa. Aluehallintovirastojen julkaisuja 33/2017.

Internet: https://www.avi.fi/documents/10191/8064383/Julkaisu-33+Omavalvonta+ymp\%C3\%A4rivuorokautisessa+vanhustenhuollossa.pdf/f594820e-081a-4985-b669ea23e9c7d1e3 (viitattu 25.6.2020).

VRN \& THL. Vireyttä seniorivuosiin - ikääntyneiden ruokasuositus. Valtion ravitsemusneuvottelukunta ja THL Ohjaus 4/2020. PunaMusta Oy, Helsinki.*

*sisältyy dokumenttianalyysin aineistoon 